\title{
Activation of Hageman Factor by Collagen
}

\author{
G. D. Wilner, H. L. Nossel, and E. C. LeRoy \\ From the Departments of Medicine and Pathology, College of Physicians and \\ Surgeons, Columbia University, New York 10032
}

A в S T R A C т Purified acid-soluble and insoluble human collagen accelerated the clotting of plateletpoor plasma in silicone-treated tubes. The clotpromoting effect did not appear to be due to thromboplastic activity since the collagen preparations did not activate factor $\mathrm{X}$ in the presence of factor VII and calcium. Instead, collagen appeared to accelerate clotting by activating Hageman factor (factor XII) on the basis of the following findings : collagen increased the clot-promoting activity of partially purified Hageman factor but exerted no further effect in the presence of kaolin, a known activator of Hageman factor; clot-promoting eluates were obtained from collagen exposed to normal, hemophilic, or PTC-deficient plasma but not from collagen exposed to Hageman or PTA-deficient plasma. The collagen molecule itself appeared to be required for the clot-promoting activity since digestion with collagenase or thermal denaturation at $\mathrm{pH} 2.5$ (about $35^{\circ} \mathrm{C}$ ) resulted in very marked reduction in clot-promoting activity. Since thermal denaturation is associated with transformation of collagen structure from triple helical to random coil form, it is suggested that the native form of collagen is essential for the ability to activate Hageman factor.

Blockage of the free amino groups by treatment with nitrous acid or dinitrofluorobenzene only slightly reduced the clot-promoting activity of collagen. In contrast, since addition of cationic proteins to collagen markedly reduced pro-coagulant activity it is suggested that negatively charged sites on the collagen molecule are critical for Hageman factor activation. This suggestion is supported by

Address requests for reprints to Dr. H. L. Nossel, Department of Medicine, Columbia University, College of Physicians and Surgeons, New York 10032.

Receiv'd for publication 25 June 1968. the finding that pepsin treatment of collagen, which removes the predominantly negatively charged telopeptides, results in significant decrease in coagulant activity. Esterification of collagen, which neutralizes $80-90 \%$ of the free carboxyl groups, reduced coagulant activity by over $90 \%$ and it is suggested that the free carboxyl groups of glutamic and aspartic acids provide the negatively charged sites critical for Hageman factor activation.

\section{INTRODUCTION}

The studies of several investigators have established that collagen causes platelet adherence and aggregation $(1,2)$. In addition to effects on platelets it has been claimed that collagen initiates the clotting process by activating Hageman factor (factor XII) $(3,4)$. One perplexing feature of these studies is the observation that increasing quantities of collagen lengthen the plasma clotting time (4) whereas all other Hageman activators shorten the plasma clotting time (5). Ratnoff (5) reported contamination of some collagen preparations with tissue thromboplastin which may have been responsible for the postulated clot-promoting effect of collagen.

In view of the uncertainty concerning the mechanism of the effect of collagen on plasma coagulation this question was restudied with emphasis on the properties of the collagen which might be responsible for clot-promoting activity.

\section{METHODS}

Venous blood was drawn from normal subjects or patients with congenital coagulation factor deficiencies using disposable 20-gauge needles and polypropylene syringes (Roehr Products Co., Deland, Fla.). The blood was anticoagulated with 0.1 volume $4 \%$ trisodium citrate (Vita- 
rine Co., New York) and processed in polystyrene tubes (Kern Chemical Corp., Los Angeles, Calif.). The tubes were inverted and centrifuged at $2000 \mathrm{~g}$ for $20 \mathrm{~min}$ at $4^{\circ} \mathrm{C}$. The supernatant plasma was centrifuged two more times at $4^{\circ} \mathrm{C}$ for $10 \mathrm{~min}$ at $20,000 \mathrm{~g}$. The resultant platelet-poor plasma containing less than 400 platelets $/ \mathrm{mm}^{3}$ was used immediately or after storage in plastic tubes at $-60^{\circ} \mathrm{C}$. All clotting tests were carried out in siliconetreated $10 \times 75 \mathrm{~mm}$ glass tubes. Glassware and pipets were treated with silicone as previously described (6).

All chemicals were reagent grade and were obtained from the following suppliers: Celite 512 from JohnsManville, New York; cytochrome $c$ (equine heart, 3 times recrystallized) from Nutritional Biochemicals Corporation, Cleveland, Ohio; spermine and lysozyme from Calbiochem, Los Angeles, Calif.; protamine sulfate from Eli Lilly \& Co., Indianapolis, Ind.; and methylene blue from J. T. Baker Chemical Co., N. Phillipsburg, N. J. Glycine- $\mathrm{HCl}$ buffer, $\mathrm{pH} 2.5,0.05 \mathrm{M}$, was made as described by Gomori (7). Calcium chloride solutions and barbital-buffered saline ( $\mathrm{pH} 7.4$ ) were made as previously described (8). Citrate-saline consisted of 5 volumes saline buffer mixed with 1 volume $4 \%$ trisodium citrate. Celite eluates were made from Celite 512 with normal plasma as previously described (9).

Several collagen preparations were used:

(a) Insoluble bovine collagen not dispersible in acid was obtained from Calbiochem (Lot 72281). The term "insoluble collagen" is used to refer to this preparation. A similar preparation obtained from Sigma Chemical Co., St. Louis, Mo. (Lot 126B-210) was tested for tissue thromboplastic activity and found unsuitable for use in subsequent studies; see Table II.

(b) Acid-soluble human fetal skin collagen (tropocollagen) was prepared from the skin of a stillborn infant by the method of Gallop and Seifter (10). This preparation is referred to as "soluble collagen."

(c) Acid-dispersible polymerized human adult skin collagen was extracted from cadaver skin by the Nishihara method as modified by Steven and Jackson $(11,29)$. The term Nishihara collagen is used to refer to this preparation. $100 \mathrm{~g}$ corium, obtained by removing keratin and subcutaneous tissues with a scalpel, was minced with a scissors, washed in cold saline, and chopped in a meat grinder precooled with dry ice. The tissue was suspended in $500-1000 \mathrm{ml}$ of cold $0.5 \mathrm{M}$ sodium acetate solution, stirred constantly for $18 \mathrm{hr}$ at $4^{\circ} \mathrm{C}$ and deposited by centrifugation. The washing with sodium acetate was repeated five times. The tissue was then stirred constantly at room temperature $\left(27^{\circ}\right)$ for $96 \mathrm{hr}$ in $500 \mathrm{ml} 0.22 \mathrm{M}$ $\mathrm{NaH}_{2} \mathrm{PO}_{4}$ buffer, $\mathrm{pH} 5.4$, containing $5 \mathrm{~g}$ crude alpha amylase (Nutritional Biochemical Corporation) and $5 \mathrm{~g}$ $\mathrm{NaCl}$. The tissue was then washed three times in cold distilled water and extracted three times with $500-\mathrm{ml}$ aliquots of cold $\left(4^{\circ} \mathrm{C}\right) 1.0 \mathrm{~N}$ acetic acid. Each extraction continued for $24 \mathrm{hr}$ at $4^{\circ}$ with constant stirring. The insoluble residue was deposited after each extraction by centrifugation at $5000 \mathrm{~g}$ for $30 \mathrm{~min}$ at $4^{\circ} \mathrm{C}$. Collagen polymers present in the supernatant were repeatedly precipitated by addition of solid $\mathrm{KCl}$ followed by cen- trifugation and redispersal in cold $1.0 \mathrm{~N}$ acetic acid. After four reprecipitations, the acid-dispersed collagen polymers were dialyzed against repeated changes of cold $0.02 \mathrm{M} \mathrm{Na}_{2} \mathrm{HPO}_{4}$ solution. The precipitated collagen was washed three times in cold distilled water, lyophylized, and stored at $-60^{\circ}$. Collagen was extracted from human dura and aorta by a similar procedure.

The collagen was suspended as follows. Lyophylized preparations were weighed out into the conical glass tube part of the Duall tissue grinder set obtained from Kontes Glass Co., Vineland, N. J. pH 7.4 buffered saline was added and the collagen suspended by the Teflon pestle attached to an electric drill which was operated until a homogeneous suspension was obtained (usually about 2 min). During the suspension the tube was inmersed in a $4^{\circ} \mathrm{C}$ ice bath. A fresh suspension was made each day. Initially, the amount of collagen added to a sample of plasma was checked by measuring the hydroxyproline content of the final mixture. The hydroxyproline content of the Nishihara collagen used was $8.5 \%$, as measured by the method of Prockop and Udenfriend (12).

Collagenase-treated collagen. $5 \mathrm{mg}$ Nishihara collagen was suspended in $5 \mathrm{ml} \mathrm{pH} 7.4$ buffered saline and $0.0025 \mathrm{M} \mathrm{CaCl}$. $0.2 \mathrm{mg}$ purified collagenase (236 U/ $\mathrm{mg}$ ) (CLSPA 7 GA, Worthington Biochemical Corporation, Freehold, N. J.) was added, and the mixture incubated at $37^{\circ}$ for $48 \mathrm{hr}$. Collagen suspended in calciumsaline without collagenase, and collagenase alone suspended in calcium-saline served as controls.

Heat denaturation (13). $2 \mathrm{mg}$ soluble collagen was dissolved in $5 \mathrm{ml}$ cold glycine- $\mathrm{HCl}$ buffer, $\mathrm{pH} 2.5$. The solution was equilibrated at the desired temperature for $30 \mathrm{~min}$, the temperature being held constant to $\pm 0.5^{\circ}$. After $30 \mathrm{~min}$, the solution was dialyzed against Veronal-

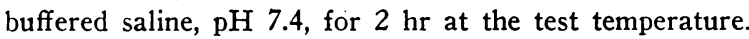
The dialyzed precipitate was then suspended and tested.

Viscosity incasurements. $2 \mathrm{mg}$ soluble collagen was dissolved in $5 \mathrm{ml}$ cold glycine- $\mathrm{HCl}$ buffer, $\mathrm{pH} 2.5$. An Ostwald type viscosimeter was filled with the collagen solution or the buffer and the instrument immersed in a water bath accurate to $\pm 0.5^{\circ} \mathrm{C}$. Measurements of capillary transit time were made in triplicate following equilibration at the test temperature for $30 \mathrm{~min}$. Relative viscosity was calculated as the ratio of the capillary transit time of the collagen soluion versus buffer alone.

Dinitrofuorobenzene (DNFB)-treated collagen (14). $100 \mathrm{mg}$ Nishihara collagen was added to a flask containing $250 \mathrm{ml} 5 \%$ aqueous $\mathrm{NaHCO}_{3}$ solution and $500 \mathrm{ml}$ of $1 \%(\mathrm{v} / \mathrm{v})$ 2,4-dinitrofluorobenzene (Calbiochem) dissolved in $95 \%$ ethanol. After being stirred at room temperature $\left(27^{\circ}\right)$ for $120 \mathrm{hr}$ the collagen was deposited by centrifugation, washed three times with large volumes of distilled water, placed on a sintered glass suction filter, and extracted repeatedly with distilled water, followed by three extractions with ethanol and three extractions with acetone. The acetone-dried collagen was stored at $-60^{\circ}$ and suspended in buffered saline immediately before testing.

Acidificd methanol-trcated collagen (methanol collagen) (15). $100 \mathrm{mg}$ Nishihara collagen was added to $200 \mathrm{ml}$ 
absolute methanol containing $1.5 \mathrm{ml}$ concentrated $\mathrm{HCl}$ solution. The mixture was stirred constantly at room temperature $\left(27^{\circ}\right)$ for $72 \mathrm{hr}$. The collagen was deposited by centrifugation, suspended in $50 \mathrm{ml}$ cold distilled water, and dialyzed exhaustively against cold distilled water. The collagen was lyophylized, stored at $-60^{\circ}$, and suspended in buffered saline, $\mathrm{pH} 7.4$, immediately before testing.

Deamination of collagen (16). The entire procedure was carried out at room temperature $\left(27^{\circ} \mathrm{C}\right) .100 \mathrm{mg}$ Nishihara collagen was suspended in $20 \mathrm{ml}$ distilled water and stirred constantly for $18 \mathrm{hr} .10 \mathrm{~g}$ dry $\mathrm{NaNO}_{2}$ and then $50 \mathrm{ml}$ glacial acetic acid were added. $\mathrm{CO}_{2}$ gas was constantly bubbled through the reaction mixture to minimize oxidation of the nitrous acid and to provide agitation. After $24 \mathrm{hr}$ an additional $10 \mathrm{~g}$ of $\mathrm{NaNO}_{2}$ and $50 \mathrm{ml}$ glacial acetic acid was added to the mixture. After a further $24 \mathrm{hr}$ the collagen was washed three times with $10 \%$ sodium chloride, transferred to a sintered glass suction filter, washed repeatedly with distilled water, and then dried with acetone.

Pepsin treatment of collagen (17). Nishihara collagen was treated with pepsin (twice recrystallized, Worthington Biochemical Co.) as described by Rubin, Drake, Davison, Pfahl, Speakman, and Schmitt (17). With minor modifications $10 \mathrm{mg}$ collagen was dissolved in $5 \mathrm{ml}$ glycine- $\mathrm{HCl}$ buffer ( $\mathrm{pH}$ 2.5). $5 \mathrm{ml}$ pepsin solution in glycine- $\mathrm{HCl}$ containing $0.2 \mathrm{mg}$ pepsin/ $\mathrm{ml}$ was added and the solution was stirred for $24 \mathrm{hr}$ at room temperature $\left(27^{\circ}\right)$. The collagen-pepsin suspension was then dialyzed against

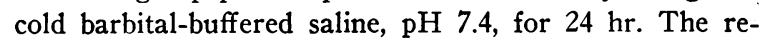
sultant dialyzed precipitate was redispersed in $7 \mathrm{ml}$ glycine- $\mathrm{HCl}(\mathrm{pH} 2.5)$, reprecipitated with dry $\mathrm{KCl}$, deposited by centrifugation, and washed three times with $10-\mathrm{ml}$ volumes of distilled water. The product was lyophilized and stored at $-60^{\circ} \mathrm{C}$.

Collagen eluates. $20 \mathrm{mg}$ insoluble collagen was incubated with $1 \mathrm{ml}$ platelet-poor plasma in a silicone-treated tube for $10 \mathrm{~min}$ at $37^{\circ} \mathrm{C}$. The collagen was deposited by centrifugation, washed six times with distilled water, and then eluted for $10 \mathrm{~min}$ at $37^{\circ}$ with $2 \mathrm{ml} 1.54 \mathrm{M}$ sodium chloride, buffered with sodium barbital at $\mathrm{pH}$ 7.4. The eluate was dialyzed against saline buffer for $18 \mathrm{hr}$ at $4^{\circ}$ before being tested.

Hageman factor was purified as described by Ratnoff and Davie (18). Using the definition proposed by these workers, that $1 \mathrm{U}$ of Hageman factor is the amount of activity present in $1 \mathrm{ml}$ of pooled normal human plasma, the preparation used had a specific activity of 10 and was free of other known clotting factor activities. Anti-activated PTA, an alpha globulin present in normal plasma, was prepared as described by Niemetz and Nossel (19).

The clot-promoting activity of collagen was measured as follows: $0.1 \mathrm{ml}$ collagen suspension was added to 0.1 $\mathrm{ml}$ platelet-poor plasma in a silicone-treated tube at $37^{\circ} \mathrm{C}$. $0.1 \mathrm{ml}$ cephalin (Thrombofax, Ortho Pharmaceutical Co., Raritan, N. J.) and $0.1 \mathrm{ml} 0.025 \mathrm{M} \mathrm{CaCl}_{2}$ were added immediately or after incubating the collagen with the plasma for 5 or $10 \mathrm{~min}$ at $37^{\circ} \mathrm{C}$. Five amounts (usually 100,50 , 25,10 , and $5 \mu \mathrm{g}$ ) of the control and test collagen prepara- tions were tested and the clotting times plotted against collagen content on double logarithmic paper. Lines were drawn through the points obtained for each collagen preparation. The activity of the test collagen preparation was calculated as a percentage of that of the control collagen preparation.

Tissue thromboplastin test. A barium sulfate eluate of normal human serum containing factors VII and X was prepared as described by Biggs and Macfarlane (8) and concentrated so that factor VII and $\mathrm{X}$ activity was equal to that of a pool of 10 normal plasma samples. The eluate protein content was $6 \mathrm{mg} / \mathrm{ml} .0 .2 \mathrm{ml} \mathrm{BaSO}$, eluate, $0.4 \mathrm{ml}$ saline, $0.2 \mathrm{ml} 0.025 \mathrm{M} \mathrm{CaCl}_{2}$, and the test addition were mixed and incubated for $5 \mathrm{~min}$ at $37^{\circ} \mathrm{C}$. At intervals, $0.1 \mathrm{ml}$ of this mixture was added to a clotting tube containing $0.1 \mathrm{ml}$ factor $\mathrm{X}$-deficient plasma (Diagnostic Reagents, Thame, Oxford, England) and $0.1 \mathrm{ml}$ cephalin. $0.1 \mathrm{ml} 0.025 \mathrm{M} \mathrm{CaCl}_{2}$ was added and the clotting time recorded. The tissue thromboplastin preparations tested were extracts of rabbit brain obtained from Difco Laboratories, Detroit, Michigan.

\section{RESULTS}

Incubation of purified collagen with normal plasma shortens the plasma clotting time (Fig. 1). All collagen preparations produced qualitatively similar clot-promoting effects. The clot-promoting effect of the collagen preparation was greatly reduced by prior treatment with collagenase (Table I). The collagen preparations used failed to activate a preparation with factor VII and $\mathrm{X}$ activity in the presence of calcium, whereas crude connective tissue preparations, collagen obtained from Sigma Chemical Co. and tissue thromboplastin in amounts

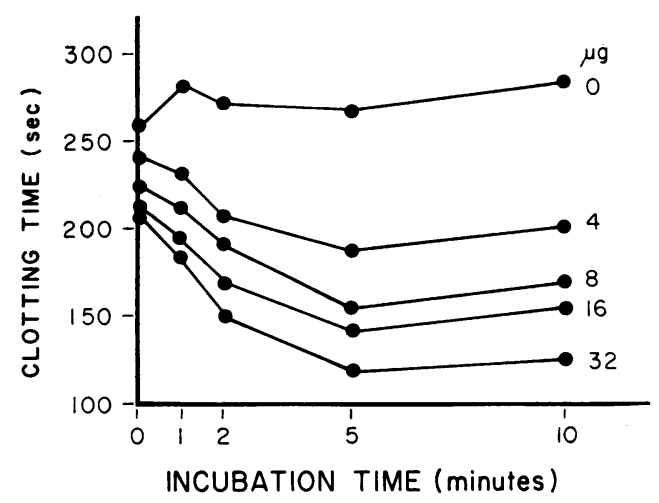

FIGURE 1 The effect of collagen on the clotting time of platelet-poor plasma. The clotting mixtures consisted of $0.1 \mathrm{ml}$ normal plasma, $0.1 \mathrm{ml}$ Nishihara collagen incubated at $37^{\circ}$ as indicated, $0.1 \mathrm{ml}$ cephalin, and $0.1 \mathrm{ml}$ $\mathrm{CaCl}_{2} 0.025 \mathrm{M}$. The amount of collagen added is shown by the numerals in micrograms next to each curve. The tests were carried out in silicone-treated tubes. 
TABLE I

Effect of Collagenase Treatment on the Clot-Promoting Activity of Collagen

\begin{tabular}{lccc}
\hline & \multicolumn{3}{c}{ Clotting time } \\
\cline { 2 - 4 } & \multicolumn{3}{c}{ Incubation time (min) } \\
\cline { 2 - 4 } Addition & 0 & 5 & 10 \\
\hline $\begin{array}{l}\text { Citrate-saline } \\
\begin{array}{l}\text { Nishihara collagen treated } \\
\text { with saline }\end{array}\end{array}$ & 287 & 290 & 297 \\
$\begin{array}{l}\text { Nishihara collagen treated } \\
\text { with collagenase }\end{array}$ & 243 & 197 & 159 \\
\hline
\end{tabular}

The tests were carried out in silicone-treated tubes. $0.1 \mathrm{ml}$ addition in citrate-saline was added to $0.1 \mathrm{ml}$ platelet-free plasma and after incubation at $37^{\circ} \mathrm{C} 0.1 \mathrm{ml}$ cephalin and $0.050 \mathrm{M} \mathrm{CaCl}_{2}$ were added and the clotting time was recorded. $100 \mu \mathrm{g}$ collagen was added.

down to $8 \times 10^{-5} \mu \mathrm{g}$ reacted with the factor VII and $\mathrm{X}$ preparation in clot-promoting reactions (Table II).

To localize the site of action of collagen we investigated the effect of collagen on the clotting time of plasma samples lacking specific coagula-

TABLE II

Tissue Thromboplastic Effect of Collagen Preparations

\begin{tabular}{|c|c|c|c|}
\hline \multirow[b]{3}{*}{ Test material $(\mu \mathrm{g})$} & \multicolumn{3}{|c|}{ Clotting time } \\
\hline & \multicolumn{3}{|c|}{ Incubation time $(\mathrm{min})$} \\
\hline & $\mathbf{0}$ & 3 & 5 \\
\hline & \multicolumn{3}{|c|}{ sec } \\
\hline Saline control & 249 & 228 & 202 \\
\hline Thromboplastin $80 \mu \mathrm{g}$ & 13 & 10 & 8 \\
\hline $8 \mu \mathrm{g}$ & 30 & 16 & 11 \\
\hline $8 \times 10^{-1} \mu \mathrm{g}$ & 54 & 36 & 31 \\
\hline $8 \times 10^{-2} \mu \mathrm{g}$ & 85 & 50 & 44 \\
\hline $8 \times 10^{-3} \mu \mathrm{g}$ & 144 & 103 & 76 \\
\hline $8 \times 10^{-5} \mu \mathrm{g}$ & 211 & 193 & 161 \\
\hline $8 \times 10^{-7} \mu \mathrm{g}$ & 224 & 218 & 212 \\
\hline Insoluble collagen (Sigma)* & 233 & 216 & 165 \\
\hline Insoluble collagen (Calbiochem) & 265 & 228 & 234 \\
\hline Soluble collagen & 229 & 221 & 215 \\
\hline Nishihara skin collagen & 235 & 221 & 235 \\
\hline Connective tissue + & 141 & 26 & 18 \\
\hline
\end{tabular}

Incubation mixture: $100 \mu \mathrm{g}$ collagen in $0.2 \mathrm{ml}$ saline or 0.2 $\mathrm{ml}$ thromboplastin, connective tissue, or saline; $0.2 \mathrm{ml}$ $\mathrm{BaSO}_{4}$ eluate; $0.4 \mathrm{ml}$ saline; $0.2 \mathrm{ml} \mathrm{CaCl}{ }_{2} 0.025 \mathrm{M}$. Incubate at $37^{\circ} \mathrm{C}$. Clotting mixture: $0.1 \mathrm{ml} \mathrm{Factor} \mathrm{X}$-deficient plasma; $0.1 \mathrm{ml}$ cephalin; $0.1 \mathrm{ml}$ incubation mixture; $0.1 \mathrm{ml}$ $\mathrm{CaCl}_{2} 0.025$ M.

* See text.

$\ddagger$ Prepared by the method of Zucker and Borrelli (1).
TABLE III

Effect of Collagen on the Clotting Time of Plasma Deficient in Different Coagulation Factors

\begin{tabular}{|c|c|c|c|c|}
\hline \multirow[b]{2}{*}{ Plasma tested } & \multicolumn{4}{|c|}{ Clotting time } \\
\hline & Saline & $\begin{array}{c}\text { Nishihara } \\
\text { collagen }\end{array}$ & Celite & $\begin{array}{c}\text { Nishihara } \\
\text { collagen } \\
\text { plus } \\
\text { Celite }\end{array}$ \\
\hline & \multicolumn{4}{|c|}{$\sec$} \\
\hline $\begin{array}{l}\text { Normal } \\
\text { Hemophilic (factor }\end{array}$ & 291 & 138 & 52 & 51 \\
\hline VIII-deficient) & 4260 & 691 & 207 & 194 \\
\hline \multicolumn{5}{|l|}{ Christmas disease } \\
\hline (factor IX-deficient) & 9000 & 1440 & 290 & 282 \\
\hline Factor XI-deficient & 1050 & 750 & 308 & 360 \\
\hline Factor XII-deficient & 1300 & 855 & 370 & 370 \\
\hline
\end{tabular}

The tests were carried out in silicone-treated tubes. Clotting mixtures consisted of : $0.1 \mathrm{ml}$ plasma, $0.1 \mathrm{ml}$ saline or collagen $(40 \mu \mathrm{g})$ or Celite ( $2 \mathrm{mg}$ ), and $0.1 \mathrm{ml}$ saline or Celite; incubated at $37^{\circ} \mathrm{C}$ for $10 \mathrm{~min}$, and additions of $0.1 \mathrm{ml}$ cephalin and $0.1 \mathrm{ml} \mathrm{CaCl}_{2} 0.025 \mathrm{M}$.

tion factors. Collagen caused relatively less acceleration of the clotting time of factor XII- or XI-deficient plasma than of normal, factor VIIIor IX-deficient plasma and did not further accelerate the clotting time of any plasma tested in the presence of Celite (Table III). Eluates were made from collagen exposed to normal plasma or plasma deficient in different clotting factors. The coagulant effect of eluates made from normal, factor VIII- or IX-deficient plasma was much greater than the effect of eluates made from factor XI- or XII-deficient plasma (Table IV). The clot-promoting activity of the collagen eluate was destroyed by a purified anti-activated factor XI preparation. After $3 \mathrm{hr}$ incubation with saline at $37^{\circ} \mathrm{C}$ a collagen eluate caused normal plasma to clot in 126

TABLE IV

Coagulant Effect of Collagen Eluates made from Plasma Samples Deficient in Different Factors

\begin{tabular}{lc}
\hline $\begin{array}{c}\text { Eluate made from } 20 \mathrm{mg} \text { insoluble } \\
\text { collagen exposed to } 1 \mathrm{ml} \text { of : }\end{array}$ & Clotting time \\
\hline & $\mathrm{sec}$ \\
Normal plasma & 125 \\
Factor VIII-deficient plasma & 120 \\
Factor IX-deficient plasma & 107 \\
Factor XI-deficient plasma & 185 \\
Factor XII-deficient plasma & 198 \\
Saline control & 186 \\
\hline
\end{tabular}

The tests were carried out in silicone-treated tubes. The clotting mixtures consisted of : $0.1 \mathrm{ml}$ noncontact plasma, $0.1 \mathrm{ml}$ cephalin, $0.1 \mathrm{ml}$ eluate or saline, and $0.1 \mathrm{ml} 0.025 \mathrm{M}$ $\mathrm{CaCl}_{2}$. 
TABLE V

Effect of Collagen Eluates on the Clotting Time of Plasma Samples Deficient in Different Coagulation Factors

\begin{tabular}{lrrr}
\hline & \multicolumn{3}{c}{ Clotting time } \\
\cline { 2 - 4 } \multicolumn{1}{c}{ Plasma } & Saline & $\begin{array}{c}\text { Collagen } \\
\text { eluate* }\end{array}$ & $\begin{array}{c}\text { Celite } \\
\text { eluate }\end{array}$ \\
\hline & & sec \\
Normal & 54 & 55 & 51 \\
Factor VIII-deficient & 168 & 163 & 163 \\
Factor IX-deficient & 218 & 140 & 210 \\
Factor XI-deficient & 234 & 122 & 66 \\
Factor XII-deficient & 272 & 135 & 63 \\
\hline
\end{tabular}

The tests were carried out in silicone-treated tubes. Clotting mixtures consisted of: $0.1 \mathrm{ml}$ plasma, $0.1 \mathrm{ml}$ cephalin, and $0.1 \mathrm{ml}$ kaolin $(5 \mathrm{mg} / \mathrm{ml})$ incubated at $37^{\circ} \mathrm{C}$ for $5 \mathrm{~min}$ and $0.1 \mathrm{ml}$ saline or eluate, and $0.1 \mathrm{ml}_{\mathbf{L}} \mathrm{CaCl}_{2}$ $0.025 \mathrm{M}$.

* Insoluble collagen.

sec, whereas after incubation with an anti-activated factor XI preparation the collagen eluate caused the plasma to clot in $203 \mathrm{sec}$. Collagen eluates markedly shortened the clotting time of plasma pre-incubated with kaolin and lacking factor IX, XI, or XII activity but did not shorten the clotting time of normal or factor VIII-deficient plasma
(Table V). Celite eluates replace factor XII and $\mathrm{XI}$ activity to a much greater extent than collagen eluates do but are free of factor IX activity (Table $\mathrm{V})$. The clot-promoting activity of a purified Hageman factor preparation was markedly increased by kaolin, a substance known to activate Hageman factor (22-25), as well as by collagen (Fig. 2). When purified Hageman factor was mixed with kaolin and collagen no further increase in clotpromoting activity occurred (Table VI). This result is compatible with the thesis that the two materials affect the same stage of the clotting process.

The physical and chemical properties of the collagen preparations responsible for their clot-promoting effect were next investigated. The effect of stepwise thermal denaturation at $\mathrm{pH} 2.5$ of acidsoluble human fetal skin collagen is shown in Fig. 3 . There was a parallel reduction in relative viscosity and clot-promoting activity, both functions showing a sharp decline at about $35^{\circ}$. Addition to collagen of positively charged substances such as cytochrome $c$, lysozyme, protamine, or spermine prevented the formation of collagen eluate procoagulant activity as well as the clot-promoting effect of collagen on normal plasma. After $10 \mathrm{~min}$ incubation at $37^{\circ}$, collagen shortened the cletting

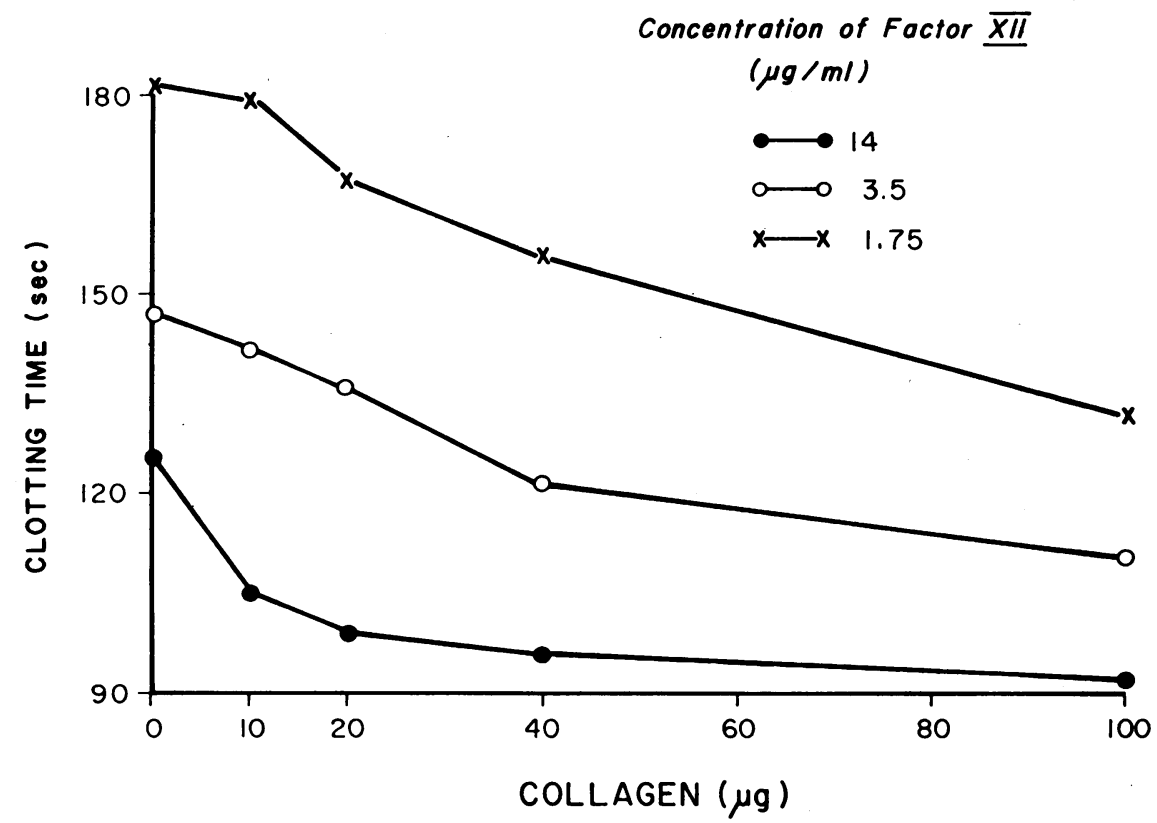

FIGURE 2 The effect of collagen on the clot-promoting activity of purified factor XII. Clotting time of a mixture of $0.1 \mathrm{ml}$ Nishihara collagen, $0.1 \mathrm{ml}$ factor XII, $0.1 \mathrm{ml}$ factor XII-deficient plasma, incubated $5 \mathrm{~min}$ at $37^{\circ} \mathrm{C}, 0.1 \mathrm{ml}$ cephalin, and $0.1 \mathrm{ml}$ $\mathrm{CaCl}_{2} 0.025 \mathrm{M}$. The tests were carried out in silicone-treated tubes. 


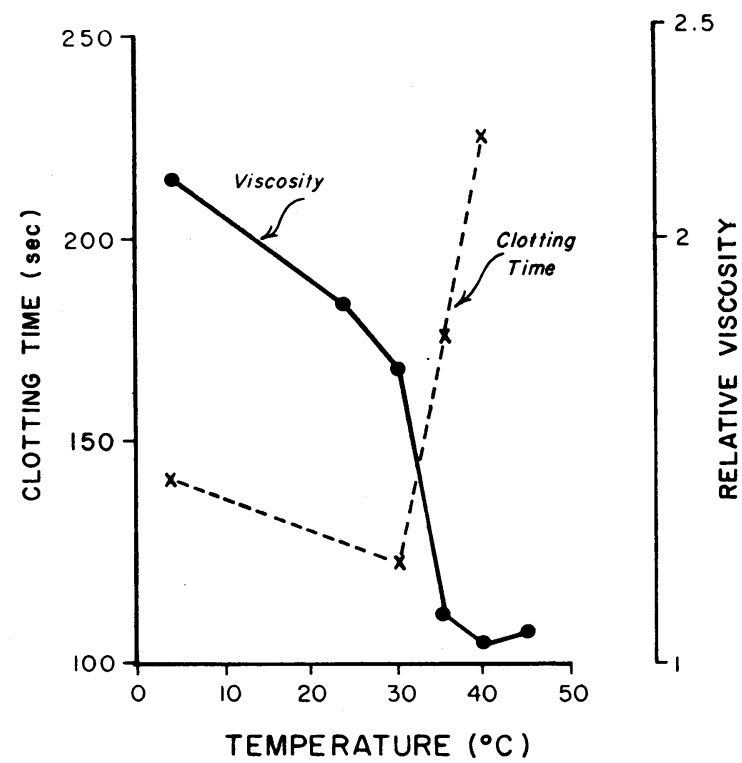

FIgURE 3 Comparison of relative viscosity and plasma clot-promoting activity of soluble collagen heated to different temperatures at $\mathrm{pH} 2.5$. The clotting test system was: $0.1 \mathrm{ml}$ plasma and $0.1 \mathrm{ml}$ collagen $(40 \mu \mathrm{g})$ incubated at $37^{\circ}$ for $10 \mathrm{~min} .0 .1 \mathrm{ml}$ cephalin and $0.1 \mathrm{ml} \mathrm{CaCl}$ $0.025 \mathrm{M}$ were then added. The tests were carried out in silicone-treated tubes.

time of plasma to $95 \mathrm{sec}$ compared to $220 \mathrm{sec}$ for saline. Prior addition of cytochrome $c$ to collagen resulted in a clotting time of $205 \mathrm{sec}$. Removal of the telopeptides from the collagen molecule by treatment with pepsin reduced coagulant activity approximately $50 \%$. Esterification of the free

TABLE VI

Effect of Kaolin and Collagen on the Clot-Promoting Effect of Purified Hageman Factor

\begin{tabular}{lr}
\hline \multicolumn{1}{c}{ Test mixture } & $\begin{array}{c}\text { Clotting } \\
\text { time }\end{array}$ \\
\hline & sec \\
Hageman factor + saline & 190 \\
Hageman factor + Nishihara collagen & 126 \\
Hageman factor + kaolin & 81 \\
Hageman factor + kaolin + Nishihara collagen & 79 \\
Nishihara collagen + saline & 670 \\
Kaolin + saline & 280 \\
Saline & 1450 \\
\hline
\end{tabular}

The tests were carried out in silicone-treated tubes. Clotting time of a mixture of $0.1 \mathrm{ml}$ Hageman factor (3.5 $\mu \mathrm{g} / \mathrm{ml})$ or saline, $0.1 \mathrm{ml}$ saline or collagen $(100 \mu \mathrm{g})$ or kaolin $(10 \mathrm{mg} / \mathrm{ml}), 0.1 \mathrm{ml}$ saline or collagen $(100 \mu \mathrm{g})$, and $0.1 \mathrm{ml}$ Hageman-deficient plasma incubated for $5 \mathrm{~min}$ at $37^{\circ} \mathrm{C}$ and $0.1 \mathrm{ml}$ cephalin and $0.1 \mathrm{ml} \mathrm{CaCl}_{2} 0.025 \mathrm{M}$. carboxyl groups by methanol treatment virtually abolished the coagulant activity of collagen whereas blockage of the epsilon amino groups with DNFB and blockage of the amino groups by deamination only slightly impaired the clot-promoting activity of collagen.

\section{DISCUSSION}

The results shown in Fig. 1 indicate that collagen accelerates the clotting of normal plateletfree plasma. The marked reduction of the coagulant effect by collagenase treatment provides evidence that the clot-promoting effect of the collagen preparations is due to the collagen molecule itself and not to a trace contaminant. This thesis is supported by the observation that parallel loss of viscosity and clot-promoting effect accompanied heating to $35^{\circ} \mathrm{C}$ at acid $\mathrm{pH}$ since human collagen alters from the helical to a random coil conformation at about $36^{\circ}(20)$.

Very much smaller quantities of collagen (4-32 $\mu \mathrm{g}$ ) were used in this study than were reported by Niewiarowski to prolong the clotting time of plasma $(10-50 \mathrm{mg})(4)$. In the present investigation $5-20 \mathrm{mg}$ of bovine tendon collagen preparations/ml of plasma also shortened clotting times. Selective adsorption of Hageman factor was not achieved with any of our preparations of collagen. The reason for the differences from Niewiarowski's findings is not clear. Possible explanations may involve differences in the physical state of the different collagen preparations (21) or impurities present in the collagen preparations.

The results of the experiments described in Table II indicate that the collagen preparations used in the present experiments contained no thromboplastic activity when tested by a method sensitive to $8 \times 10^{-5} \mu \mathrm{g}$ amounts of thromboplastin and hence that the pro-coagulant activity of collagen was unlikely to be due to thromboplastin contamination.

The question then arises as to the site of action of collagen. The results recorded in Table III indicate that collagen greatly accelerated the clotting time of normal plasma or of plasma deficient in factor VIII or IX activity but had a lesser clotpromoting effect on plasma lacking factors XI or XII. In the presence of Celite, collagen produced little or no further acceleration of clotting. These results suggest that collagen affects the same 
stages of coagulation as Celite which, like kaolin and glass, has been shown to activate factors XII and XI $(9,22-25)$.

As recorded in Table IV, clot-promoting eluates were obtained from collagen exposed to normal plasma or plasma lacking factor VIII or IX activity but not from plasma lacking factor XI or XII activity. These results indicate that factors $\mathrm{XII}$ and XI are required for the formation of collagen eluate activity. A major part of the clotpromoting activity is probably activated factor XI since a purified anti-activated factor XI preparation destroyed the activity. As indicated by the results shown in Table $\mathrm{V}$ collagen eluate partially replaced factor XII and XI activity and not factor VIII activity, as do activated factor XI preparations. Collagen eluates made from normal or factor VIII-deficient plasma also contained factor IX activity on repeated examination but eluates made from factor IX-deficient plasma did not accelerate the clotting of factor IX-deficient plasma. The amount of factor IX adsorbed was in the range of $0.5-4 \%$ of the amount present in the plasma. Collagen did not, however, accelerate the activation of factor IX by an activated factor XI preparation when tested in a previously described system for studying factor IX activation (30).

The results are compatible with an action of collagen on Hageman factor. Further support for the idea that collagen activates Hageman factor is provided by the results of the experiments recorded in Fig. 2 which indicate that collagen increases the clot-promoting activity of purified Hageman factor. In the presence of kaolin, collagen exerted no further clot-promoting effect on purified Hageman factor (Table VI). Had collagen and kaolin acted at different stages a further acceleration of clotting would have been expected. All the results are compatible with the thesis that collagen activates Hageman factor and thereby accelerates the clotting of plasma.

The remaining experiments were devoted to investigating the physical and chemical properties of the collagen molecule responsible for its ability to activate the Hageman factor. The reduction in viscosity of collagen solutions resulting from exposure to different temperatures is accompanied by transition of collagen from a triple helical to a random coil form $(13,26,29)$. The parallel reduction of viscosity and coagulant activity (Fig. 3) suggests that the native structure of collagen is necessary for its ability to activate Hageman factor. It is not clear why this should be so. Most other Hageman factor activators are insoluble and have sites of negative surface charge which, it has been suggested, are critical for adsorption and activation of the coagulation protein (6). Ratnoff and Crum (27) demonstrated Hageman factor activation by soluble ellagic acid. In studying congeners of ellagic acid these workers thought that rigidity of structure provided by lactone bridges was critical for the ability to activate Hageman factor. It might be postulated that the collagen helix provides a rigid setting for the binding sites and that attachment of the Hageman factor to the rigidly spaced binding sites results in conformational changes in the protein which manifest as biological activation. Alternative explanations for the inactivity of the random coil form have not been excluded. For example, it is possible that intra- or interchain neutralization of the polar groups might occur.

The neutralization of the coagulant activity of collagen by positively charged substances such as cytochrome is in keeping with the previous observations that positively charged substances neutralize Hageman factor activators (6). Support for the suggestion that negatively charged sites are critical for Hageman factor adsorption and activation is provided by two positive and one negative set of results. Pepsin treatment of collagen removes the telopeptides which constitute $1 \%$ by weight of the tropocollagen molecule but contain approximately twice the concentration of glutamic and aspartic acid residues as the parent molecule (17). Such treatment reduces collagen coagulant activity by about $50 \%$. Esterification of collagen which neutralizes about $80-90 \%$ of the carboxyl groups $(15,28)$ almost completely abolishes Hageman factor activation. In contrast, blockage of the epsilon amino groups by DNFB treatment $(14,28)$ does not affect clot-promoting activity, and treatment of the collagen with nitrous acid which replaces all the free amino groups with hydroxyl groups and $20 \%$ of the guanidyl groups with cyanamide groups causes only slight reduction in clot-promoting activity.

From the results of these experiments it is concluded that the free carboxyl groups of glutamic and aspartic acids are critical for the ability of 
collagen to activate Hageman factor. This conclusion supports the previous suggestion that negatively charged sites are critical for adsorption and activation of Hageman factor (6).

\section{ACKNOWLEDGMENTS}

We wish to thank Dr. Karl Meyer for his kindly interest and helpful discussions and Mrs. Rosario Hsieh and $\mathrm{Mr}$. Michael Drillings for their excellent technical work.

This work was supported in part by NIH grants HE 10999, $\mathrm{He} 05741$, and T01 CA 05151, and grants from the U. S. Public Health Service, The RGK Foundation, Austin, Texas, and the John A. Hartford Foundation, New York.

\section{REFERENCES}

1. Zucker, M. B., and J. Borrelli. 1962. Platelet clumping produced by connective tissue suspensions and by collagen. Proc. Soc. Exptl. Biol. Med. 109: 779.

2. Spaet, T. H., J. Cintron, and M. Spivack. 1962. Some properties of platelet connective tissue mixed agglutination reaction. Proc. Soc. Exptl. Biol. Med. 111: 292.

3. Niewiarowski, S., E. Bankowski, and T. Fiedoruk. 1964. Adsorption of Hageman factor (XII) on collagen. Experientia. 20: 367.

4. Niewiarowski, S., E. Bankowski, and I. Rogowicka. 1965. Studies on the adsorption and activation of Hageman factor (Factor XII) by collagen and elastin. Thromb. Diath. Haemorrhag. 14: 387.

5. Ratnoff, O. D. 1966. The biology and pathology of the initial stages of blood coagulation. In Progress in Hematology. E. Brown and C. V. Moore, editors. Grune \& Stratton, Inc., New York. 5: 210.

6. Nossel, H. L., H. Rubin, M. Drillings, and R. Hsieh. 1968. Inhibition of Hageman factor activation. $J$. Clin. Invest. 47: 1172.

7. Gomori, G. 1955. Preparations of buffers for use in enzyme studies. Methods Enzymol. 1: 139.

8. Biggs, R., and R. G. Macfarlane. 1962. Human Blood Coagulation and Its Disorders. Blackwell Scientific Publications Ltd., Oxford, England. 3rd edition.

9. Nossel, H. L. 1964. The Contact Phase of Blood Coagulation. Blackwell Scientific Publications Ltd., Oxford, England.

10. Gallop, P. M., and S. Seifter. 1963. Preparation and properties of soluble collagens. Methods Enzymol. 6: 635 .

11. Steven, F. S., and D. S. Jackson. 1967. Purification and amino acid composition of monomeric and polymeric collagens. Biochem. J. 104: 534.

12. Prockop, D. J., and S. Udenfriend. 1960. A specific method for the analysis of hydroxyproline in tissues and urine. Anal. Biochem. 1: 228.
13. Burge, R. E., and R. D. Hynes. 1959. The thermal denaturation of collagen in solution and its structural implications. J. Mol. Biol. 1: 155.

14. Bowes, J. H., and J. A. Moss. 1953. The reaction of fluorodinitrobenzene with $\alpha$ and $\epsilon$-amino groups of collagen. Biochem. J. 55: 735.

15. Olcott, H. S., and H. Fraenkel-Conrat. 1947. Specific group reagents for proteins. Chem. Rev. 41: 151.

16. Bowes, J. H., and R. H. Kenten. 1949. The effect of deamination and esterification on the reactivity of collagen. Biochem. J. 44: 142.

17. Rubin, A. L., M. Drake, P. Davison, D. Pfahl, P. Speakman, and F. O. Schmitt. 1965. Effects of pepsin treatment on the interaction properties of tropocollagen macromolecules. Biochemistry. 4: 181.

18. Ratnoff, O. D., and E. W. Davie. 1962. The purification of activated Hageman factor (activated Factor XII). Biochemistry. 1: 967.

19. Niemetz, J., and H. L. Nossel. 1967. Method of purification and properties of anti-XIa (inhibitor of the contact product). Thromb. Diath. Haemorrhag. $17: 335$.

20. Bakerman, S., and R. T. Hersh. 1964. Extraction from human skin of soluble collagen molecules containing only beta components. Nature. 201: 190.

21. Bianchi, E., G. Conio, A. Ciferri, D. Puett, and L. Rajagh. 1967. The role of $\mathrm{pH}$, temperature, salt type, and salt concentration on the stability of crystalline, helical, and randomly coiled forms of collagen. $J$. Biol. Chem. 242: 1361.

22. Margolis, J. 1957. Initiation of blood coagulation by glass and related surfaces. J. Physiol. 137: 95.

23. Ratnoff, O. D. and J. M. Rosenblum. 1958. Role of Hageman factor in the initiation of clotting by glass. Am. J. Med. 25: 160.

24. Waaler, B. A. 1959. Contact activation in the intrinsic blood clotting system. Studies on a plasma product formed on contact with glass and similar surfaces. Scand. J. Clin. Lab. Invest. 11 (Suppl. 37) : 1.

25. Soulier, J.-P., and O. Prou-Wartelle, O. 1960. New data on Hageman factor and plasma thromboplastin antecedent: the role of "contact" in the initial phase of blood coagulation. Brit. J. Haematol. 6: 88 .

26. Engel, J. 1962. Investigation of the denaturation and renaturation of soluble collagen by light scattering. Arch. Biochem. 97: 150.

27. Ratnoff, O. D., and J. D. Crum. 1964. Activation of Hageman factor by solutions of ellagic acid. J. Lab. Clin. Med. 63: 359.

28. Gustavson, K. H. 1956. The chemistry and reactivity of collagen. Academic Press, New York.

29. Steven, F. S. 1964. The Nishihara technique for the solubilization of collagen. Ann. Rheumatic Diseases. 23: 300 .

30. Nossel, H. L. 1964. The activation and consumption of Factor IX. Thromb. Diath. Haemorrhag. 12: 505. 